\title{
What has been done, what has yet to be done
}

\author{
Javier Tourón ${ }^{\star}$ \\ University of Navarra, Spain, Center for Talented Youth Spain
}

By the end of this special issue the reader should have a clearer picture of what has been done with respect to the contribution of the Center for Talented Youth (CTY) model to gifted education. We have come a long way from the seminal works by Terman, the luminous ideas of Leta S. Hollingworth and those of other eminent scholars in the field.

In many respects, from a personal point of view, the work done by Stanley at the inception of the CTY model (based on the ideas and principles of the 'Study of Mathematically Precocious Youth') could be considered even more important than those mentioned above, but he was also in debt to previous contributions to the field made by others. This is the way scientific knowledge progresses. As with a large wall made of bricks, some researchers may put in a few bricks, others hundreds and a few perhaps thousands. However, the wall at the end is built up as a common construction where every piece is essential, where every line of bricks needs to be there before the next one is laid, in order that the whole will be sound and durable.

There is no question about the magnitude of the contribution of the model described here, both in the USA and world wide. Its success is well beyond the limits of any initial prediction that could have been made at the beginning by Stanley and his associates. Today millions of students have benefited from the talent searches, programs and services provided by the universities and institutions implementing this model, or other similar models inspired by its rationale. Moreover, the research effort made to validate the model and the educational practices derived from it have been very influential in the shaping of appropriate legislation and the adaptation of school practice in many places.

Something apparently so simple as annual talent searches permit us to:

give gifted education names, faces, and numbers. Above-level test scores speak louder than the most insistent parent does. Before the talent searches, no one believed that the highest-performing middle-school students could score as well as high school seniors on college entrance exams. (USA Today, 1999; cited in Ybarra, 2005).

Chapter six of the recent report $A$ nation deceived (Colangelo et al., 2004), entitled the 'Talent search revolution', quotes extensively from Stanley, and emphasizes the

^Departmento de Educación, Universidad de Navarra, Campus Universitario s/n, 31080 Pamplona, Spain. Email: jtouron@unav.es 
tremendous increase in the searches year after year. In a section entitled 'From a dozen to 200.000' the authors pointed out:

Imagine, every five years, a total of one million capable junior-high school students actually take a college-entrance exam, at least four years before the usual age ... . And they don't take the test just to test. Most importantly, testing with talent search opens the door to real opportunities for these students. (Colangelo et al., 2004, Vol. I, p. 26).

This was a big step ahead, no doubt.

Even so, we are not done. Indeed, we are still far from an acceptable situation. Many voices have been voicing a need for serious attention to gifted students, both for their own well-being and for the benefits they can offer to the societies in which they live (cf. US Department of Education, 1983, 1993). There is a clear tendency in many places to postpone support for gifted education in favor of other priorities that many administrations consider more urgent. Frequently gifted education risks being seen as the 'cherry on top', i.e. as something desirable but dispensable. Gifted education has to wait until other priorities are attended to, with the result that it is all too often ignored.

The situation is unacceptable in many places, as many have pointed out. As one example, Davidson and Davidson (2004) recently stated in their book Genius denied that

There are hundreds of thousands of highly gifted children in the U.S. and millions more whose intelligence is above average, yet few receive the education they deserve. Many school districts have no gifted programs or offer only token enrichment classes. Education of the gifted is in this sorry state, because of indifference, lack of funding, and the pernicious notion that education should have a 'levelling' effect, a one-size-fits-all concept that deliberately ignores the needs of the gifted. But all children are entitled to an appropriate education, those left behind as well as those who want to surge ahead.

Even in North America, which is the pioneer in gifted education services and research and where the greatest number of initiatives are available for gifted students, the situation is by no means satisfactory in many states. (For detailed information see Policy and legislation state by state at http:/www.geniusdenied.com/ StatePolicy.aspx.)

The situation of gifted education is even worse in many European countries. There are roughly three distinct groups of countries: one group with no legislation (although some facilities are provided); another group with legislation, but with a lack of real interest in promoting the excellence of their most capable students (see Tourón et al., 2005); another group of countries with no legislation and no provision for handling gifted students differently, or even where such provision is prohibited. Funding of gifted programs is a rarity in most countries.

As can be easily understood, it is impossible in this space to give even a brief idea of what is going on in Europe because of the great differences between countries. Fortunately, several sources are available for the interested reader. For a general overview a good source is the second edition of the Handbook edited by Heller et al. (2000; see also Heller et al., 1993). A comparison of the two could give an idea of progress made in the intervening years. 
However, perhaps more interesting is the report sponsored by the Bundesministerium für Bildung und Forschung (German Federal Ministry of Education) in which the situation of 21 European countries is analyzed and compared in detail (in German, available at http://www.socsci.kun.nl/psy/cbo/ publicaties.htm). An updated version, in English, including data until December 2004, is available at: http://www.bmbf.de/pub/gifted_education_21_eu_countries.pdf.

Looking to the future, at the beginning of the 21 st century, despite the differences between countries and even continents, I think that a number of common priorities can be delineated to improve the services for the gifted everywhere in the world. I will mention just a few, based on my understanding of the most urgent needs.

1. Early identification of the talented is a priority, as it is the natural first step in planning the educational programs and services for those identified. That talent not identified is at risk of being lost. If we do not undertake early detection, through regularly established talent searches (something that is scarce or non-existent in Europe), we will be losing time that is precious to these gifted students. There are different approaches to gifted education and diverse conceptions of giftedness and educational planning. It is true that concept, identification and programs have to be linked coherently, but whatever the theoretical approach we might adopt, one thing is crucial, early detection is essential in any educational system that wants to be proactive and not reactive. Do we know who the 2,3 or $5 \%$ of most capable students in our schools are? I am afraid that we all know the answer is too often no. This clearly means that we are putting in jeopardy the possibility of talent development for many students, particularly those who are at risk for various reasons: marginality, immigration, disability, lack of resources, etc. In addition, students not at risk are in danger of losing an important developmental opportunity.

2. Another important course of action involves teacher training. There are many initiatives in Europe, America and other parts of the world involving national agencies, diplomas of specialist in gifted education, masters degrees, etc. Nevertheless, teacher training in gifted education is still very scarce. In many areas teachers lack the minimum qualifications to handle the needs of gifted students, despite the fact that many countries have as one principle of their educational laws attention to diversity and to the special educational needs deriving from it. Teachers in many schools, even those trying to do their best, are inadequately trained to serve gifted students. Further, they are unable to recognize gifted students due to their lack of qualifications. Teacher formation (initial and in-service training) is an urgent priority in order to modify teacher attitudes towards the gifted. The literature offers ample evidence of the impact of teacher knowledge about gifted education on the attitudes exhibited by the teacher in the classroom.

3. Finally, we should create areas for joint efforts in research and for sharing our best practices and experiences with others. In a world which is progressively more globalized the exchange of knowledge has to be more and more fluid. 
Moreover, if we make an effort to base our actions on rigorous and wellfounded research we will be in a better position to influence the administrative and legislative decisions needed to foster talent development.

Whatever we do, the highly able students will still be there in schools. Hence, we need to do our best to ensure that we don't jeopardize their welfare through lack of knowledge, inappropriate actions or neglect. (C. M. Callahan, Journal for the Education of the Gifted, 19(2), p. 149).

\section{References}

Callahan, C. M. (1996) Fournal for the Education of the Gifted, 19(2), 149.

Colangelo, N., Assouline, S. \& Gross, M. (2004) A nation deceived: how schools hold back America's brightest students, The Templeton National Report on Acceleration (Iowa City, IA, University of Iowa). Available online at: http://www.nationdeceived.org (accessed 26 May 2005).

Davidson, J. \& Davidson, B. (2004) Genius denied. How to stop wasting our brightest young minds (New York, Simon \& Shuster).

Heller, K. A., Mönks, F. J. \& Passow, A. H. (Eds) (1993) International handbook of research and development of giftedness and talent (Oxford, Pergamon Press).

Heller, K. A., Mönks, F. J., Sternberg, R. \& Subotnik, R. (Eds) (2000) International handbook of research and development of giftedness and talent (Oxford, Pergamon Press).

Tourón, J., Tourón, M. \& Silvero, M. (2005) The Center for Talented Youth Spain: an initiative to serve highly able students, High Ability Studies, 16(1), 121-135.

US Department of Education (1983) A nation at risk. Available online at: http://www.ed.gov/pubs/ NatAtRisk/risk.html (accessed 26 May 2005).

US Department of Education (1993) National excellence: a case for developing America's talent. Available online at: http://www.ed.gov/pubs/ DevTalent/toc.html (accessed 26 May 2005).

Ybarra, L. (2005) Beyond national borders: the Johns Hopkins University Center for Talented Youth reaching out to gifted children from throughout the world, High Ability Studies, 16(1), $15-26$. 